\title{
Kinetic and Mechanistic Investigations of Oxidation of Myo-Inositol by Diperiodatocuprate(III) in Aqueous Alkaline Medium
}

\author{
G.T.NAYAK ${ }^{1}$, C.C.HADIMANI ${ }^{*}$ and A.L.HARIHAR ${ }^{2}$ \\ ${ }^{1}$ Chemistry Department, B.V. B. College of Engineering and Technology, \\ Hubli, Karnataka, India \\ ${ }^{2}$ Chemistry Department, Kittle Science College, Dharwad, Karnataka, India \\ cc_hadimani@bvb.edu
}

Received 5 September 2014 / Accepted 25 September 2014

\begin{abstract}
The kinetics of oxidation of myo-inositol (INOS) by diperiodatocuprate(III) (DPC) in aqueous alkaline medium at a constant ionic strength of $0.07 \mathrm{~mol} / \mathrm{dm}^{3}$ was studied spectrophotometrically. The reaction between DPC and INOS in alkaline medium exhibits 1:1 stoichiometry. The reaction is of first order in DPC and less than unit order in INOS. The rate constants increase with increase in alkali concentration. Periodate has retarding effect on the rate of reaction. The reaction rate decreases with increase in ionic strength and decrease in dielectric constant of the medium. The main products were identified by spot test and spectral studies. A suitable mechanism was proposed on the basis of experimental results. The reaction constants involved in the different steps of the reaction mechanism were calculated. The activation parameters with respect to the slow step of the mechanism were determined.
\end{abstract}

Keywords: Diperiodatocuprate(III), Kinetics, Myo-inositol, Oxidation

\section{Introduction}

Myo-inositol is a water soluble six membered cyclic polyol, which is snthesised by both eukaryotes and prokaryote ${ }^{1}$. In humans most inositol is sythesised to an extent of few grams per day ${ }^{2}$ in the kidneys. Myo-inositol and some of its mono and polyphosphates function as the basis for a number of signaling and secondary messenger molecules. These are involved in insulin signal transduction ${ }^{3}$, gene expression ${ }^{4,5}$ breakdown of fats and reducing blood cholesterol $^{6}$, phosphorus storage $^{7,8}$ and oligosaccharide synthesis ${ }^{9}$.

Oxidation of myo-inositol was studied by different oxidants like alkaline potassium periodate ${ }^{10}$, alkaline hexacyano ferrate(III) ion in presence of $\mathrm{Os}^{\mathrm{VIII}}, \mathrm{V}^{\mathrm{V}}$ in acid medium ${ }^{11}$ in absence $^{12}$ and presence ${ }^{13}$ of $\mathrm{Cu}^{\mathrm{II}}$, periodic acid ${ }^{14,15}$. The literature survey reveals that there are no reports on the mechanistic studies of myo-inositol oxidation by DPC in alkaline medium. The title reaction was studied to investigate the redox chemistry of $\mathrm{Cu}^{\mathrm{III}}$ in aqueous alkaline medium and to arrive plausible mechanism. 


\section{Experimental}

All chemicals used were of reagent grade and double distilled water was used throughout the work. A solution of INOS (Merk) was prepared by dissolving an appropriate amount of recrystallized sample was prepared in double distilled water. The copper(III) periodate complex was prepared ${ }^{16}$ and standardized by the standard procedure ${ }^{17 a}$. All other reagents, namely $\mathrm{KOH}, \mathrm{KNO}_{3}, \mathrm{CuSO}_{4}$ and $\mathrm{KIO}_{4}$ were of analar grade.

\section{Kinetic measurements}

Kinetic measurements were performed by monitoring absorbance changes using a spectrophotometer with fully thermostated cell compartment. All kinetic measurements were performed in glass stoppered Pyrex boiling tubes coated black to eliminate photochemical effects. The reactions were carried out under pseudo-first order conditions by taking a known excess of INOS over DPC at $301 \mathrm{~K}$. Appropriate amounts of INOS, $\mathrm{KOH}, \mathrm{KNO}_{3}$ and water to keep the total volume constant were equilibrated at constant temperature $\left( \pm 0.1{ }^{\circ} \mathrm{C}\right)$. A measured amount of DPC solution also pre-equilibrated at the same temperature was rapidly added to the mixture. The progress of reaction was followed by measuring the absorbance of unreacted DPC in the reaction mixture present in $1 \mathrm{~cm}$ cell in a thermostated compartment of a Varian CARY 50 Bio UV-Vis spectrophotometer (Varian, Victoria - 3170, Austrilia) at $415 \mathrm{~nm}$. It was verified that other constituents of the reaction mixture do not absorb significantly at this wavelength. The application of Beer's law to DPC at $415 \mathrm{~nm}$ had been verified and extinction coefficient, $C$, was found to be $6250 \pm 50 \mathrm{dm}^{3} \mathrm{~mol}^{-1} \mathrm{~cm}^{-1}$. The pseudo-first-order rate constants, $\mathrm{k}_{\mathrm{obs}}$ calculated from the linear plots of $\log [\mathrm{DPC}]$ versus time were reproducible within $\pm 4 \%$ and are average of at least three independent kinetic runs. The plots were linear over $85 \%$ completion of the reaction (Figure 1). Regression analysis of experimental data to obtain regression coefficient $r$ and the standard deviation $S$, of points from the regression line, was performed with the Microsoft Excel programme.



Figure 1. First order plots for the oxidation of inositol by diperiodatocuprate(III) in aqueous alkaline medium at $28{ }^{\circ} \mathrm{C} ;[$ inositol $]=1 \times 10^{-4} ;\left[\mathrm{OH}^{-}\right]=0.01 \mathrm{M} ; I=0.07 \mathrm{~mol} \mathrm{dm}^{-3} ;[\mathrm{DPC}] \mathrm{x}$ $10^{5} \mathrm{~mol} \mathrm{dm}^{-3}$ : (1) 0.2 (2) 0.5 (3) 0.7 (4) 1.0 and (5) 2.0

\section{Results and Discussion}

Stoichiometry and product analysis

Different sets of concentrations of reactants in $0.01 \mathrm{~mol} \mathrm{dm}^{-3} \mathrm{KOH}$ and at constant ionic strength, $I=0.07 \mathrm{~mol} \mathrm{dm}^{-3}$ were kept in a closed container under nitrogen atmosphere at $28{ }^{\circ} \mathrm{C}$. After one hour DPC concentration was assayed by measuring the absorbance at $415 \mathrm{~nm}$. The results indicate that two moles of DPC reacts with one mole of inositol, as shown in equation (1). The main reaction products were identified as $\mathrm{Cu}^{\mathrm{II}}$ and inosose. 
The formation of $\mathrm{Cu}^{\mathrm{II}}$ is identified by its color and inosose was tested spectrophotometrically by addition of 2, 4- dinitrophenylhydrazine to the reaction mixture, following a method described in the literature ${ }^{17 b}$. The ketone was identified by the observation of two absorbance bands at 430 and $510 \mathrm{~nm}$ characteristic of the 2,4-dinitrophenylhydrazone derivative.

\section{Reaction}

$\mathrm{C}_{6} \mathrm{H}_{12} \mathrm{O}_{6}+\left[\mathrm{Cu}(\mathrm{OH})_{2}\left(\mathrm{H}_{3} \mathrm{IO}_{6}\right)\right]^{-}+2 \mathrm{OH}^{-}=\mathrm{C}_{6} \mathrm{H}_{11} \mathrm{O}_{6}+\mathrm{Cu}(\mathrm{OH})_{2}+\mathrm{H}_{2} \mathrm{IO}_{6}{ }^{3-}+2 \mathrm{H}_{2} \mathrm{O}$

\section{Reaction order}

The orders were determined from the slopes of $\log \mathrm{k}_{\mathrm{obs}}$ versus $\log$ [concentration] plots by varying the concentrations of inositol, $\mathrm{KOH}$ and $\mathrm{KIO}_{4}$, in turn, while keeping others constant.

\section{Effect of DPC}

At constant concentrations of inositol, $\mathrm{KOH}$ and other conditions constant, the DPC concentration was varied between $2 \times 10^{-6}$ to $2 \times 10^{-5} \mathrm{~mol} \mathrm{dm}^{-3}$. The plot of $\log [\mathrm{DPC}]$ versus time, was linear over more than three half lives of the reaction for different initial DPC concentration (Figure 1), which indicates the first order with respect to DPC concentration. This was also confirmed by the almost constant values of pseudo-first order rate constant, $\mathrm{k}_{\mathrm{obs}}$ for different DPC concentration (Table 1).

Table 1. Effect of the variation of DPC, INOS, $\mathrm{OH}^{-}$and $\mathrm{IO}_{4}{ }^{-}$concentrations on diperiodatocuprate(III) oxidation of inositol in aqueous alkaline medium at $28{ }^{\circ} \mathrm{C}, I=0.07 \mathrm{~mol} \mathrm{dm}^{-3}$

\begin{tabular}{cccccc}
\hline $\begin{array}{c}{[\mathrm{DPC}] 10^{6}} \\
\mathrm{~mol} \mathrm{dm}^{-3}\end{array}$ & $\begin{array}{c}{[\mathrm{INOS}] 10^{4}} \\
\mathrm{~mol} \mathrm{dm}^{-3}\end{array}$ & $\begin{array}{c}{\left[\mathrm{IO}_{4}^{-}\right] 10^{6}} \\
\mathrm{~mol} \mathrm{dm}^{-3}\end{array}$ & $\begin{array}{c}{\left[\mathrm{OH}^{-}\right] 10^{2}} \\
\mathrm{~mol} \mathrm{dm}^{-3}\end{array}$ & $\mathrm{k}_{\mathrm{obs} \times 10^{2} \mathrm{~s}^{-1}}$ & $\mathrm{k}_{\mathrm{cal}} \times 10^{2} \mathrm{~s}^{-1}$ \\
\hline 2.0 & 1.0 & 2.0 & 1.0 & 18.23 & 18.20 \\
5.0 & 1.0 & 2.0 & 1.0 & 18.23 & 18.20 \\
7.0 & 1.0 & 2.0 & 1.0 & 18.23 & 18.20 \\
10.0 & 1.0 & 2.0 & 1.0 & 18.23 & 18.20 \\
20.0 & 1.0 & 2.0 & 1.0 & 18.23 & 18.20 \\
7.0 & 0.2 & 2.0 & 1.0 & 6.00 & 5.98 \\
7.0 & 0.5 & 2.0 & 1.0 & 12.04 & 12.05 \\
7.0 & 1.0 & 2.0 & 1.0 & 18.23 & 18.20 \\
7.0 & 1.5 & 2.0 & 1.0 & 21.78 & 21.78 \\
7.0 & 2.0 & 2.0 & 1.0 & 24.45 & 24.44 \\
7.0 & 1.0 & 2.0 & 1.0 & 18.23 & 18.20 \\
7.0 & 1.0 & 5.0 & 1.0 & 17.58 & 17.60 \\
7.0 & 1.0 & 7.0 & 1.0 & 17.23 & 17.25 \\
7.0 & 1.0 & 10.0 & 1.0 & 16.74 & 16.73 \\
7.0 & 1.0 & 20.0 & 1.0 & 15.20 & 15.19 \\
7.0 & 1.0 & 2.0 & 0.002 & 1.75 & 1.74 \\
7.0 & 1.0 & 2.0 & 0.02 & 9.40 & 9.42 \\
7.0 & 1.0 & 2.0 & 0.2 & 16.91 & 16.92 \\
7.0 & 1.0 & 2.0 & 1.0 & 18.23 & 18.20 \\
7.0 & 1.0 & 2.0 & 2.0 & 18.36 & 18.37 \\
\hline
\end{tabular}




\section{Effect of inositol}

The inositol concentration was varied in the concentration range $2 \times 10^{-5}$ to $2 \times 10^{-4} \mathrm{~mol} \mathrm{dm}^{-3}$ at constant alkali, $0.01 \mathrm{~mol} \mathrm{dm}{ }^{-3}$, constant ionic strength, $0.07 \mathrm{~mol} \mathrm{dm}^{-3}$ and constant $\mathrm{IO}_{4}^{-}$ concentration, $2 \times 10^{-6}$. As the inositol concentration increases the rate of reaction also increases (Table 1). The order with respect to inositol was found to be less than unity (Figure 2).

\section{Effect of alkali and periodate}

The effect of alkali concentration on the reaction was studied at constant concentrations of inositol and DPC at a constant ionic strength of $0.07 \mathrm{~mol} \mathrm{dm}^{-3}$ at $28{ }^{\circ} \mathrm{C}$. The rate constants increased with an increase in alkali concentration (Table 1). The order with respect to alkali was found to be less than unity (Figure 2 ). The effect of $\left[\mathrm{IO}_{4}^{-}\right]$was observed by varying the concentration from $2 \times 10^{-6}$ to $2 \times 10^{-2} \mathrm{~mol} \mathrm{dm}^{-3}$, keeping all other reactants concentrations constant. It was found that the rate constants decreased with an increase in $\mathrm{KIO}_{4}$ concentration (Table 1).

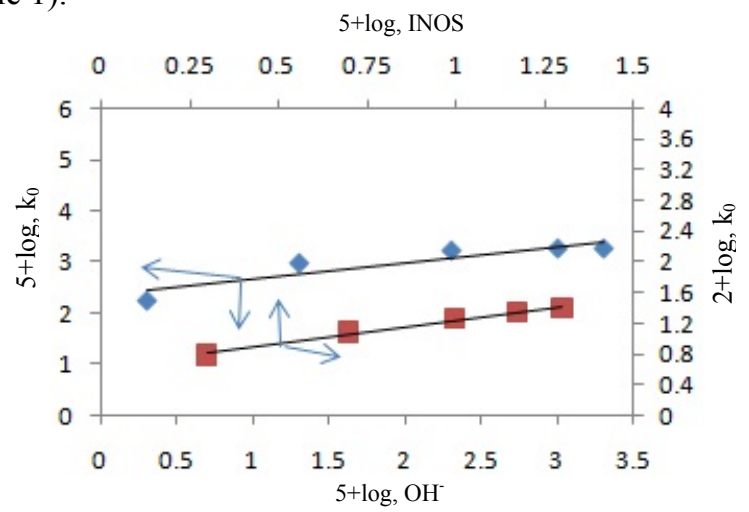

Figure 2. Order with respect to inositol and $\mathrm{OH}^{-}$ion concentrations on the oxidation of inositol by diperiodatocuprate(III) in aqueous alkaline medium at $301 \mathrm{~K}$.(Conditions as in the Table 1)

\section{Effect of ionic strength and dielectric constant}

The effect of ionic strength was studied by varying the potassium nitrate concentration from $2 \times 10^{-5}$ to $2 \times 10^{-2} \mathrm{~mol} \mathrm{dm}^{-3}$ at constant concentrations of DPC, inositol alkali and $\mathrm{KIO}_{4}$. It was found that the rate constant decreased with increase in concentration of $\mathrm{KNO}_{3}$ and the plot of $\log _{\mathrm{obs}}$ versus $1 / \sqrt{\mathrm{I}}$ was linear $(\mathrm{r} \geq 0.877)$ with negative slope.

Dimethyl sulphoxide (DMSO) is a dipolar aprotic solvent and it has a dielectric constant less than that of water. To find out the effect of dielectric constant (D) on the rate of oxidation in aqueous alkaline medium, the reactions have been carried out at various proportions of DMSO in the medium. The $\mathrm{D}$ values were calculated from the equation $\mathrm{D}=$ $D_{W} V_{W}+D_{D} V_{D}$, where $D_{w}$ and $D_{D}$ are dielectric constants of pure water and DMSO respectively and $V_{w}$ and $V_{D}$ are the volume fractions of components of water and DMSO respectively in the total mixture. With an increase in the percentage of DMSO, the rate of the reaction decreased. In other words, the decrease in dielectric constant of the reaction medium had retarded the rate of reaction. It appears that the reaction is between negative ion and a dipole? ${ }^{9}$. Hence, in aqueous alkaline medium, the reaction is between ion $\left[\mathrm{Cu}(\mathrm{OH})_{2}\left(\mathrm{H}_{3} \mathrm{IO}_{6}\right)\right]^{-}$and inositol molecule. 


\section{Effect of added product}

The externally added product, $\mathrm{Cu}^{\mathrm{II}}$ in the range $1.0 \times 10^{-4}$ to $1.0 \times 10^{-3} \mathrm{~mol} \mathrm{dm}^{-3}$ did not have any significant effect on the rate of the reaction.

\section{Polymerization study}

To test the intervention of free radicals, the reaction mixture, to which a known quantity of acrylonitrile (scavenger) had been added initially, was kept for two hours under nitrogen atmosphere. On dilution with methanol, no precipitate of polymer was formed, indicating the absence of intervention of free radicals in the reaction.

\section{Effect of temperature}

The rate constants increased with an increase in temperature. The plot of lnk versus 1/T yield straight line and the values of activation parameters viz. enthalpy of activation $\left(\Delta \mathrm{H}^{\#}\right)$, entropy of activation $\left(\Delta S^{\#}\right)$ and Gibb's free energy $\left(\Delta G^{\#}\right)$ are evaluated from the slope of the plot by using the Eyring equation ${ }^{18,19}$ and are tabulated (Table 2).

\section{Discussion}

The water soluble copper(III) periodate complex was reported ${ }^{20}$ to be $\left[\mathrm{Cu}\left(\mathrm{HIO}_{6}\right)_{2}(\mathrm{OH})_{2}\right]^{7-}$. However, in an aqueous alkaline medium and at a high $\mathrm{pH}$ range employed in the study, periodate is unlikely to exist as $\mathrm{HIO}_{6}{ }^{4-}$ (as is present in the complex) as is evident from its involvement in the multiple equilibria ${ }^{21}(1)-(3)$, depending on the $\mathrm{pH}$ of the solution

$$
\begin{aligned}
\mathrm{H}_{5} \mathrm{IO}_{6} & =\mathrm{H}_{4} \mathrm{IO}_{6}{ }^{-}+\mathrm{H}^{+} ; \mathrm{K}_{1}=5.1 \times 10^{-4} \\
\mathrm{H}_{4} \mathrm{IO}_{6}{ }^{-} & =\mathrm{H}_{3} \mathrm{IO}_{6}{ }^{2-}+\mathrm{H}^{+} ; \mathrm{K}_{2}=4.9 \times 10^{-9} \\
\mathrm{H}_{3} \mathrm{IO}_{6}{ }^{2-} & =\mathrm{H}_{2} \mathrm{IO}_{6}{ }^{-}+\mathrm{H}^{+} ; \mathrm{K}_{3}=2.5 \times 10^{-12}
\end{aligned}
$$

Periodic acid exists as $\mathrm{H}_{5} \mathrm{IO}_{6}$ in acid medium and as $\mathrm{H}_{4} \mathrm{IO}_{6}{ }^{-}$near $\mathrm{pH}$ 7. Hence, under alkaline conditions as employed in this study the main species are expected to be $\mathrm{H}_{3} \mathrm{IO}^{2-}$ and $\mathrm{H}_{2} \mathrm{IO}_{6}{ }^{3-}$. Thus at the $\mathrm{pH}$ employed in this study the soluble copper(III) periodate complex might be $\left[\mathrm{Cu}(\mathrm{OH})_{2}\left(\mathrm{H}_{3} \mathrm{IO}_{6}\right)_{2}\right]^{3-}$ a conclusion also supported by earlier work ${ }^{22,23}$.

In most of the reports ${ }^{24}$ on DPC oxidation, both $\mathrm{OH}^{-}$and periodate retarding effect on the rate of reaction. However, in the present kinetic study, different kinetic results have been obtained. In this study periodate had a retarding effect and $\mathrm{OH}^{-}$had an increasing effect on the rate of reaction (Table 1). The result of increase in rate of reaction with increase in alkalinity can be explained in terms of prevailing equilibrium of formation in terms of $\left[\mathrm{Cu}(\mathrm{OH})_{2}\left(\mathrm{H}_{3} \mathrm{IO}_{6}\right)\left(\mathrm{H}_{2} \mathrm{IO}_{6}\right)\right]^{4-}$ from $\left[\mathrm{Cu}(\mathrm{OH})_{2}\left(\mathrm{H}_{3} \mathrm{IO}_{6}\right)_{2}\right]^{3-}$ and $\mathrm{OH}^{-}$as given in the following equation (4)

$$
\left[\mathrm{Cu}(\mathrm{OH})_{2}\left(\mathrm{H}_{3} \mathrm{IO}_{6}\right)_{2}\right]^{3-}+\mathrm{OH}^{-} \stackrel{\mathrm{K}_{4}}{=}\left[\mathrm{Cu}(\mathrm{OH})_{2}\left(\mathrm{H}_{3} \mathrm{IO}_{6}\right)\left(\mathrm{H}_{2} \mathrm{IO}_{6}\right)\right]^{4-}+\mathrm{H}_{2} \mathrm{O}
$$

Also decrease in the rate with increase in $\left[\mathrm{H}_{3} \mathrm{IO}_{6}{ }^{2-}\right]$ (Table 1) suggest that equilibrium of copper(III) periodate complex to form monoperiodatocuprate(III) (MPC) species as given in equation (5) is established.

$$
\left[\mathrm{Cu}(\mathrm{OH})_{2}\left(\mathrm{H}_{3} \mathrm{IO}_{6}\right)\left(\mathrm{H}_{2} \mathrm{IO}_{6}\right)\right]^{-4} \stackrel{\mathrm{K}_{5}}{=}\left[\mathrm{Cu}(\mathrm{OH})_{2}\left(\mathrm{H}_{3} \mathrm{IO}_{6}\right)\right]^{-}+\mathrm{H}_{3} \mathrm{IO}_{6}{ }^{2-}
$$

Such type of equilibria (4) and (5) have been well noticed in literature ${ }^{25}$. It may be expected that a lower periodate complex such as monoperiodatocuprate(III) (MPC) is more important in the reaction than the DPC. The inverse fractional order in $\left[\mathrm{H}_{3} \mathrm{IO}_{6}{ }^{2-}\right]$ might also be due to this reason. Therefore, MPC might be the main reactive form of the oxidant. 
The less than unit order in inositol presumably results from formation of a complex, $\mathrm{C}$ (green colour), between the MPC species and inositol prior to the formation of the products. $\mathrm{K}_{6}$ is the composite equilibrium constant comprising the equilibrium to bind active species, MPC to inositol species to form a complex, C. The formation of complex was proved kinetically by Michaelis - Menten plot i.e., a non zero intercept of the plot $1 / \mathrm{k}_{\mathrm{obs}} v s$. $1 /[$ INOS] (Figure 3). The evidence for complex formation was also obtained in aqueous alkaline media from the UV-Vis spectrum of both DPC and inositol and DPC-inositol mixtures in which a bathochromic shift of $5 \mathrm{~nm}$ from $271 \mathrm{~nm}$ to $276 \mathrm{~nm}$ and hyperchromicity at $278 \mathrm{~nm}$ was observed. The complex formation between oxidant and substrate was also observed in literature ${ }^{26}$. This complex, $\mathrm{C}$, undergoes decomposition in a slow step to give the final products inosose, $\mathrm{Cu}^{\mathrm{II}}$ and periodate. From Scheme 1, the rate law (11) can be derived as follows;

$$
\begin{aligned}
& \text { Rate }=\frac{-\mathrm{d}[\mathrm{DPC})]}{\mathrm{dt}}=\mathrm{k}[\mathrm{C}]
\end{aligned}
$$

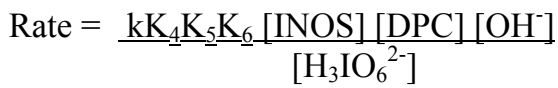

$$
\begin{aligned}
& {[\mathrm{DPC}]_{\mathrm{T}}=[\mathrm{DPC}]_{\mathrm{f}}+\left[\mathrm{Cu}(\mathrm{OH})_{2}\left(\mathrm{H}_{3} \mathrm{IO}_{6}\right)\left(\mathrm{H}_{2} \mathrm{IO}_{6}\right)\right]^{4-}+\left[\mathrm{Cu}(\mathrm{OH})_{2}\left(\mathrm{H}_{3} \mathrm{IO}_{6}\right)\right]^{-}+[\text {complex, C] }}
\end{aligned}
$$

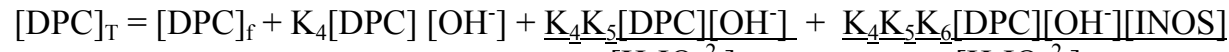

$$
\begin{aligned}
& \frac{\left[\mathrm{H}_{3} \mathrm{IO}_{6}{ }^{2-}\right]}{\left[\mathrm{H}_{3} \mathrm{IO}_{6}{ }^{2-}\right]} \\
& {[\mathrm{DPC}]_{\mathrm{T}}=[\mathrm{DPC}]_{\mathrm{f}}\left\{1+\mathrm{K}_{4}\left[\mathrm{OH}^{-}\right]+\underline{\mathrm{K}}_{4} \underline{\mathrm{K}}_{5}\left[\mathrm{OH}^{-}\right]+\underline{\mathrm{K}}_{4} \underline{\mathrm{K}}_{\underline{5}} \underline{\mathrm{K}}_{6}\left[\mathrm{OH}^{-}\right][\mathrm{INOS}]\right\}} \\
& {\left[\mathrm{H}_{3} \mathrm{IO}_{6}^{2-}\right] \quad\left[\mathrm{H}_{3} \mathrm{IO}_{6}^{2-}\right]} \\
& {[\mathrm{DPC}]_{\mathrm{f}}=} \\
& {[\mathrm{DPC}]_{\mathrm{T}}\left[\mathrm{H}_{3} \underline{\mathrm{IO}}_{6}{ }^{2-}\right]} \\
& {\left[\mathrm{H}_{3} \mathrm{IO}_{6}{ }^{2-}\right]+\mathrm{K}_{4}\left[\mathrm{H}_{3} \mathrm{IO}_{6}{ }^{2-}\right]\left[\mathrm{OH}^{-}\right]+\mathrm{K}_{4} \mathrm{~K}_{5}\left[\mathrm{OH}^{-}\right]+\mathrm{K}_{4} \mathrm{~K}_{5} \mathrm{~K}_{6}\left[\mathrm{OH}^{-}\right][\mathrm{INOS}]}
\end{aligned}
$$

Where, $\mathrm{T}$ and $\mathrm{f}$ refer to total and free concentrations.

Similarly,

$[\mathrm{INOS}]_{\mathrm{T}}=[\mathrm{INOS}]_{\mathrm{f}}+[$ complex, C]

$[\mathrm{INOS}]_{\mathrm{f}}=$

$$
\frac{\left[\mathrm{INOS}_{\mathrm{T}}\left[\mathrm{H}_{3} \mathrm{IO}_{6}{ }^{2-}\right]\right.}{\left[\mathrm{H}_{3} \mathrm{IO}_{6}{ }^{2-}\right]+\mathrm{K}_{4} \mathrm{~K}_{5} \mathrm{~K}_{6}\left[\mathrm{OH}^{-}\right][\mathrm{DPC}]}
$$

In view of low concentration of DPC used, the term $\mathrm{K}_{4} \mathrm{~K}_{5} \mathrm{~K}_{6}\left[\mathrm{OH}^{-}\right][\mathrm{DPC}]$ can be neglected. Hence,

$[\mathrm{INOS}]_{\mathrm{f}}=[\mathrm{INOS}]_{\mathrm{T}}$

Similarly; $\left[\mathrm{OH}^{-}\right]_{\mathrm{f}}=\left[\mathrm{OH}^{-}\right]_{\mathrm{T}}$

Substituting (2), (3) and (4) in (1) and omitting the subscripts $\mathrm{T}$ and $\mathrm{f}$, we get,

$$
\begin{aligned}
& \text { Rate }=\frac{-\mathrm{d}[\mathrm{DPC}]}{\mathrm{dt}}=\frac{\mathrm{kK}_{4} \mathrm{~K}_{5} \mathrm{~K}_{6}[\mathrm{DPC}][\mathrm{INOS}]\left[\mathrm{OH}^{-}\right]}{\left[\mathrm{H}_{3} \mathrm{IO}_{6}{ }^{2-}\right]+\mathrm{K}_{4}\left[\mathrm{H}_{3} \mathrm{IO}_{6}{ }^{2-}\right]\left[\mathrm{OH}^{-}\right]+\mathrm{K}_{4} \mathrm{~K}_{5}\left[\mathrm{OH}^{-}\right]+\mathrm{K}_{4} \mathrm{~K}_{5} \mathrm{~K}_{6}\left[\mathrm{OH}^{-}\right][\mathrm{INOS}]} \\
& \mathrm{k}_{\mathrm{obs}}=\underline{\text { Rate }}=\frac{\mathrm{kK}_{4} \underline{\mathrm{K}}_{5} \underline{\mathrm{K}_{6}} \underline{[\mathrm{INOS}]\left[\mathrm{OH}^{-}\right]}}{[\mathrm{DPC}]\left[\mathrm{H}_{3} \mathrm{IO}_{6}{ }^{2-}\right]^{-}+\mathrm{K}_{4}} \frac{\left.\mathrm{K}_{3} \mathrm{HO}_{6}{ }^{2-}\right]\left[\mathrm{OH}^{-}\right]+\mathrm{K}_{4} \mathrm{~K}_{5}\left[\mathrm{OH}^{-}\right]+\mathrm{K}_{4} \mathrm{~K}_{5} \mathrm{~K}_{6}\left[\mathrm{OH}^{-}\right][\mathrm{INOS}]}{10)}
\end{aligned}
$$

The rate law, (10) can be rearranged in to the following form, which is suitable for verification.

$$
\frac{1}{\mathrm{k}_{\mathrm{obs}}}=\frac{\left[\mathrm{H}_{3}\right.}{\mathrm{I} \mathrm{K}_{4} \mathrm{I}_{5} \mathrm{~K}_{6}\left[{ }^{2-}\right]}+\frac{\left[\mathrm{H}^{-}\right][\mathrm{INOS}]}{\mathrm{kK}_{4} \underline{\mathrm{K}}_{5}[\mathrm{INOS}]}+\frac{1}{\mathrm{kK}_{6}[\mathrm{INOS}]}+\frac{1}{\mathrm{k}}
$$

According to Eq. (11), other conditions being constant, plots of $1 / \mathrm{k}_{\mathrm{obs}}$ versus $1 /\left[\mathrm{OH}^{-}\right](\mathrm{r} \geq$ $0.998, \mathrm{~S} \leq 0.012), 1 / \mathrm{k}_{\mathrm{obs}}$ versus $1 /[\mathrm{INOS}](\mathrm{r} \geq 0.998, \mathrm{~S} \leq 0.012)$ and $1 / \mathrm{k}_{\mathrm{obs}}$ versus $\left[\mathrm{H}_{3} \mathrm{IO}_{6}{ }^{2-}\right]$ 
$(r \geq 0.988, S \leq 0.027)$ should be linear and are to be so (Figure 3). The slopes and intercepts of such plots lead to the values of $\mathrm{K}_{4}, \mathrm{~K}_{5}, \mathrm{~K}_{6}$ and $\mathrm{k}$ as $(15.6 \pm 0.3) \mathrm{dm}^{3} \mathrm{~mol}^{-1},\left(3.3 \pm 0.1 \times 10^{-4}\right)$ mol dm${ }^{-3},\left(1.0 \pm 0.03 \times 10^{4}\right) \mathrm{dm}^{3} \mathrm{~mol}^{-1}$ and $(0.3722 \pm 0.2) \mathrm{mol} \mathrm{dm}^{-3} \mathrm{~s}^{-1}$, respectively. The value of $\mathrm{K}_{4}$ and $\mathrm{K}_{5}$ are in good agreement with earlier work $^{27}$. These constants were used to calculate the rate constants over different experimental conditions; when compared with the experimental $k_{o b s}$ values, they were found to be in reasonable agreement with each other, which fortifies Scheme 1.

$1 /\left[\mathrm{OH}^{+}\right]$



Figure 3. Verification of rate law (11) for the oxidation of inositol by diperiodatocuprate(III) in aqueous alkaline medium at $301 \mathrm{~K}$.

The effect of ionic strength and dielectric constant of the medium on the rate explains quantitatively the reaction between molecule and ion, as seen in Scheme 1. The moderate $\Delta \mathrm{H}^{\#}$ and $\Delta \mathrm{S}^{\#}$ values (Table 2) are favorable for electron transfer reaction. The negative value of $\Delta \mathrm{S}^{\#}$ suggests that the intermediate complex is more ordered than the reactants ${ }^{28}$. The observed modest enthalpy of activation and a higher rate constant for the slow step indicate that the oxidation presumably occurs via an inner sphere mechanism. This conclusion is supported by earlier observations ${ }^{29}$.

Table 2. Arrhenius parameter for inositol oxidation by DPC in aqueous alkaline medium at $28{ }^{\circ} \mathrm{C}$

\begin{tabular}{ccccc}
\hline$\Delta \mathrm{E}^{\#} \mathrm{~kJ} / \mathrm{mol}$ & $\Delta \mathrm{H}^{\#} \mathrm{~kJ} / \mathrm{mol}$ & $\Delta \mathrm{S}^{\#} \mathrm{JK}^{-1} \mathrm{~mol}^{-1}$ & $\log \mathrm{A}$ & $\Delta \mathrm{G}^{\#} \mathrm{~kJ} / \mathrm{mol}$ \\
\hline 51.927 & 49.424 & -62.43 & $7.7 \pm 0.5$ & 17.015 \\
\hline
\end{tabular}

\section{Mechanism}

1. $\left[\mathrm{Cu}(\mathrm{OH})_{2}\left(\mathrm{H}_{3} \mathrm{IO}_{6}\right)_{2}\right]^{3-}+\mathrm{OH}^{-} \stackrel{\mathrm{K}_{4}}{=}\left[\mathrm{Cu}(\mathrm{OH})_{2}\left(\mathrm{H}_{3} \mathrm{IO}_{6}\right)\left(\mathrm{H}_{2} \mathrm{IO}_{6}\right)\right]^{4-}+\mathrm{H}_{2} \mathrm{O}$

2. $\left[\mathrm{Cu}(\mathrm{OH})_{2}\left(\mathrm{H}_{3} \mathrm{IO}_{6}\right)\left(\mathrm{H}_{2} \mathrm{IO}_{6}\right)\right]^{4-} \stackrel{\mathrm{K}_{5}}{=}\left[\mathrm{Cu}(\mathrm{OH})_{2}\left(\mathrm{H}_{3} \mathrm{IO}_{6}\right)\right]^{-}+\left[\mathrm{H}_{2} \mathrm{IO}_{6}{ }^{3-}\right]$

3.

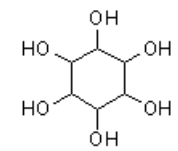

$$
\begin{gathered}
+[\mathrm{Cu}(\mathrm{OH}) \\
\frac{\text { Slow }}{\mathrm{k}}
\end{gathered}
$$

$\mathrm{K}_{6}$

4. [complex, C]

fast

$$
\text { 5. } 2 \mathrm{H}^{+}+2 \mathrm{OH}^{-} \stackrel{\text { fast }}{=} 2 \mathrm{H}_{2} \mathrm{O}
$$




\section{Conclusion}

Among the various species of DPC in aqueous alkaline medium, $\left[\mathrm{Cu}(\mathrm{OH})_{2}\left(\mathrm{H}_{3} \mathrm{IO}_{6}\right)\right]^{-}$is considered as active species for the title reaction. The results indicated that in carrying out this reaction, the role of $\mathrm{pH}$ in the reaction medium is crucial. Rate constant of slow step and other equilibrium constants involved in the mechanism are evaluated. The overall mechanistic sequence described here is consistent with all the experimental evidences including the product, spectral, mechanistic and kinetic studies.

\section{References}

1. Michell R H, Biochem Soc Symp., 2007, 74, 223-246.

2. Parthasarathy L K, Seelan R S, Tobias C, Casanova M F and Parthasarathy R N, Subcell Biochem., 2006, 39, 293-314.

3. Larner J, Int J Exp Diabetes Res., 2002, 3(1), 47-60; DOI:10.1080/15604280212528

4. Shen X, Xiao H, Ranallo R, Wu W H and Wu C, Science, 2003, 299, 112-114.

5. Steger D J, Haswell E S, Miller A L, Wente S R, O'Shea E K, Science, 2003, 299, 114-116.

6. Rapiejko P J, Northup J K, Evans T, Brown J E and Malbon C C, Biochem J., 1986, 240(1), 35-40.

7. Fujita M and Jigami Y, Biochem Biophys Acta, 2008, 1780(3), 410-420.

8. Raboy V and Bowen D, Subcell Biochem., 2006, 39,71-101.

9. Lakshman Kumar Y, Venkata Nadh R and Radhakrisnamurti P S, Asian J Chem., 2012, 24(12), 5869-5872.

10. Mehta S P S and Dhami K S, Himalayan Chem Pharm Bull., 1990, 7, 14

11. Kumar A and Rain M, Int J Chem Kinet., 1974, 6(1), 15-20;

DOI:10.1002/kin.550060103

12. Devi V L, Murthy G S S and Sushma K, Chem Commun., 1986, 12, 72.

13. Fleury P, Poirot G and Fievet M J, Compt Rend., 1945, 220, 664.

14. Fleury P, Poirot G and Fievet V, Ann Pharm Frang., 1947, 5, 209.

15. Fleury P F and Labizet I, Bull Soc Chem Boil., 1955, 37, 1099.

16. Murthy C P, Sethuram B and Navaneeth Rao T, Z Phys Chem., 1981, 262, 336.

17. Jeffery G H, Bassett J, Mendham J and Denny R C, Vogel's Textbook of Quantitative Chemical Analysis, $5^{\text {th }}$ Edition, UK:ELBS, Longman, Essex; 1966, (a) p.195 and (b) p. 455 .

18. Wynes-Jones W F K and Eyring H, J Chem Soc., 1957, 1423-1431; DOI:10.1039/JR9570001423

19. Glasstone S, Laidler K J and Eyring H, "The theory of Rate Processes", 1941, McGraw-Hill, p.196.

20. Reddy K B, Sethuram B and Navaneeth Rao T, Z Phys Chem., 1987, 268, 706.

21. Kiran T S, Hiremath C V and Nandibewoor S T, Appl Cat A: Gen.. 2006, 305(1), 79-89; DOI:10.1016/j.apcata.2006.02.047

22. W. Niu, Y. Zhu, K. Hu, C. Tong, H. Yang, Int J Chem Kinet., 1996, 28(12), 899-904; DOI:10.1002/(SICI)1097-4601(1996)28:12<899::AID-KIN6>3.0.CO;2-I

23. Jose T P and Tuwar S M, J Mol Struct., 2007, 827(1-3), 137-144; DOI:10.1016/j.molstruc.2006.05.015

24. Shetti N P, Hosamani R R and Nandibewoor S T, Open Catal J., 2009, 2, 130-139.

25. Chimatadar S A, Salunke M S and Nandibewoor S T, Indian J Chem., 2006, 45A, 338.

26. (a) Wiberg K B and Lepse P A, J Am Chem Soc., 1964, 86(13), 2612-2619; DOI:10.1021/ja01067a019 (b) Hasan F and Rocek J, J Am Chem Soc., 1975, 19, 1448. 
27. Chimatadar S A, Kini A K and Nandibewoor S T, Proceedings of the National Acadamy of Sciences India, 2007, 77, 117-121.

28. Weissberger A and Lewis E S, Investigations of Rates and Mechanistic Approach, Techniques of Chemistry, John Wiley \& Sons, New York, NY, USA, 1974.

29. Farokhi S A and Nandibewoor S T, Tetrahedron, 2003, 59(38), 7595-7602; DOI:10.1016/S0040-4020(03)01148-7 